\title{
LIETUVOS JŪRININKŲ GYVENSENOS IR SVEIKATOS YPATUMAI
}

\author{
Birutė Strukčinskienė $\dot{1}^{1}$, Inga Bartusevičiene் ${ }^{2}$, Vaiva Strukčinskaitė ${ }^{1}$, Sigutė Norkiene் $\dot{3}^{3,1}$ \\ ${ }^{1}$ Klaipédos universiteto Sveikatos mokslu fakultetas, ${ }^{2}$ Lietuvos aukštoji jüreivystès mokykla, \\ ${ }^{3}$ Klaipédos jürininku ligonine
}

Raktažodžiai: jūrininkai, gyvensena, sveikata, sveikatos stiprinimas.

\begin{abstract}
Santrauka
Jūrininkų gyvensenos ir sveikatos tyrimai yra svarbūs jūrininkų sveikatos stiprinimui. Tirti 208 Lietuvos aukštosios jūreivystės mokyklos nuolatinių ir ištęstinių studijų studentai bei kursų klausytojai (esami ir būsimi jūrininkai). 166 (79,8 proc.) apklaustieji buvo didžiają savo gyvenimo dalị pragyvenę mieste, o 42 (20,2 proc.) - kaime/rajone. Taikyta apklausa raštu. Tyrimui naudotas Klaipedos universiteto Sveikatos mokslų fakulteto ir Lietuvos aukštosios jūreivystès mokyklos mokslininkų sudarytas klausimynas. Taikytas chi kvadrato $(\chi 2)$ kriterijus. Statistinis hipotezių reikšmingumas patvirtintas, kai $p \leq 0,05$. Didžioji dauguma jūrininkų ( 87 proc.) yra kada nors rūkę per savo gyvenimą. Dabar apie pusė tiriamujų nerūko, trečdalis jūrininkų rūko kasdien, 7,2 proc. respondentų rūko kelis kartus per savaitę. Kasdien mankštinasi tik apie penktadalis tiriamujų. Daugiau nei pusė (55,8 proc.) respondentụ sportuoja kelis kartus per savaitę ( 2 ir daugiau kartų), 16,3 proc. tiriamujų sportuoja kelis kartus per mènesị, o dešimtadalis jūrininkų niekada nesimankština. Daugiau nei pusė apklaustujų dantis valo kelis kartus per dieną, apie du penktadaliai respondentų (38 proc.) dantis valosi 1 kartą per dieną, 6,7 proc. tiriamųjų dantis valosi ne kiekvieną dieną, apie 2 procentus jūrininkų dantų nesivalo niekada. Dauguma jūrininkų $(73,1$ proc.) akinių ir lęšių nenešioja. Per pastaruosius 12 mènesių dauguma respondentų (76,9 proc.) nebuvo susižeidę, penktadalis tiriamujų buvo sužaloti 1-2 kartus ir tik 2,4 procentai respondentų dẻl sužeidimų ar nelaimingų atsitikimų i medikus kreipèsi 3 ir daugiau kartų. Dažniau susižeidžia kaimo gyventojai. Per pastaruosius 12 mènesių nesirgo apie pusę (55,3 proc.) jūrininkų. 28,4 proc. tiriamųų mano, kad jų sveikata yra labai gera,
\end{abstract}

50,5 proc. - gera, 20,2 proc. - vidutinè. Jūrininkų švietimui, jų sveikos gyvensenos ịgūdžių formavimui reikètų skirti daugiau dèmesio.

\section{Ivadas}

Sveikos gyvensenos komponentai - sveika mityba, pakankamas fizinis aktyvumas, žalingų ipročių vengimas ir kiti - reikšmingai lemia individo ir visuomenès sveikatą, padeda išvengti lètinių neinfekcinių ligų ir siekti aukštesnès gyvenimo kokybès. Gyvensenos ypatumai svarbūs sveikatos stiprinimui, poliligotumo ir įvairių paplitusių susirgimų prevencijai. Jūrininkų gyvensenos ir sveikatos tyrimai svarbūs jūrininkų sveikatos stiprinimui. Jūrinių profesijų atstovų sveikatos ir saugos stiprinimo temas analizavo ịvairių pasaulio kraštų specialistai ir ekspertai [1-4]. Jūrininkų sveikatos problemas tyrè ir mūsų šalies mokslininkai [5-11]. Lietuva yra jūrinè valstybė. Lietuvoje jūros versle dirba per 12 tūkstančiu jūrininkų, iš kurių du trečdaliai jūroje dirba pastoviai [5]. V. Senčila, I. Bartusevičienè ir kt., atlikę Lietuvos jūrininkų sudèties kokybinę ir kiekybinę analizę, nustatè, kad tiriamuoju laikotarpiu Lietuvoje buvo apie 15 tūkstančių jūrininkų knygelių savininkų, ir iš jų - apie 10 tūkstančių buvo "aktyvūs" jūrininkai [6]. Jūrininkų švietimas, sveikatos stiprinimo programų ir strategijų rengimas yra aktualūs sveikatos politikos klausimai mūsų jūrinei valstybei. Anot J. Sąlygos, asmeninis požiūris ị sveikatą ir jūrininkų gyvensenos ypatumai yra svarbūs jūrininkų gyvenimo kokybės elementai [7]. S. Norkienès ir J. Sąlygos atliktuose jūrininkų tyrimuose nustatyta, kad beveik pusė jūrininkų turèjo antsvorị, o nutukę buvo 14,6 proc. jūrininkų. Be to, buvo nustatyta, kad nutukimas turi neigiamą poveiki jūrininkų su sveikata susijusios gyvenimo kokybès psichinès būsenos, energingumo/gyvybingumo ir bendro sveikatos vertinimo dimensijoms [10]. Pagal T. Carter, jūrininkai dirba išskirtinèmis sąlygomis, neturi nuolatinio prieinamumo prie sveikatos priežiūros paslaugų [4]. Taigi jūrininkų sveikatos stiprinimui ypač yra svarbios profilaktikos priemonès, sveikatos rizikos veiksnių mažinimas ir sveikos gyvensenos propagavimas. Jūrininkų 
gyvensenos ypatumų analizè, jų sveikatos ir gyvensenos tyrimai yra reikšmingi profilaktinès veiklos planavimui ir jūrininkų sveikatos gerinimui.

Darbo tikslas - analizuoti Lietuvos jūrininkų gyvensenos ir sveikatos ypatumus.

\section{Tyrimo objektas ir metodika}

Tirti 208 Lietuvos aukštosios jūreivystès mokyklos nuolatinių ir ištęstinių studijų studentai bei kursų klausytojai (esami ir būsimi jūrininkai). Taikyta apklausa raštu. Tyrimui naudotas Klaipedos universiteto Sveikatos mokslų fakulteto ir Aukštosios jūreivystès mokyklos mokslininku sudarytas klausimynas, kurị sudare sociodemografiniai klausimai ir pagrindine dalis apie respondentų gyvensenos ir sveikatos ypatumus. Tyrimas vyko paaiškinus respondentams apie tyrimą, gavus jų sutikimą ir pritarus institucijos administracijai. Statistinei duomenų analizei naudotas SPSS 21.0 programų paketas. Tyrime taikytas $\operatorname{chi}^{2}\left(\chi^{2}\right)$ kriterijus. Statistinis hipotezių reikšmingumas patvirtintas, kai $\mathrm{p} \leq 0,05$.

\section{Tyrimo rezultatai ir jų aptarimas}

Tyrime dalyvavo 198 (95,2 proc.) vyrų ir 10 (4,8 proc.) moteru. 166 (79,8 proc.) buvo miesto gyventojai, o 42 (20,2 proc.) - kaimo (rajono). 122 (58,7 proc.) respondentai -tai būsimieji jūrininkai, studijuojantys nuolatinių (dieninių) studiju programose, o 86 (41,3 proc.) tiriamieji -jau dirbantys jūroje specialistai, kurie studijuoja ištęstinių (vakarinių, neakivaizdinių) studijų programose arba yra kursų klausytojai. Pagal amžiu tiriamieji pasiskirste taip: 18-20 m.-33,2 proc., $21-25$ m. $-32,2$ proc., $26-30$ m. $-5,8$ proc., $31-45 \mathrm{~m} .-12,5$ proc., $46 \mathrm{~m}$. ir daugiau $-16,3$ proc.

Apklausos metu buvo domètasi žalingais rūkymo ịpročiais. Tyrimo metu nustatyta, kad didžioji dauguma respondentų (87 proc.) yra kada nors rūkę, 13 proc. - niekada nèra rūkę per savo gyvenimą. Statistiškai reikšmingų skirtumų tarp didžiają savo gyvenimo dalị mieste ir kaime gyvenusiu jūrininkų pagal šị požymị nèra $\left(\mathrm{x}^{2}=0,633 ; 11 \mathrm{~s}=1 ; \mathrm{p}=0,426\right)$. Tyrimo rezultatai atskleide, kaip dažnai jūrininkai rūko dabar. Apie pusė tiriamujų (47,6 proc.) nerūko niekada, trečdalis (32,7 proc.) jūrininkų rūko kasdien, 12,5 proc. - rūko kelis kartus per mėnesị, o 7,2 proc. respondentų rūko kelis

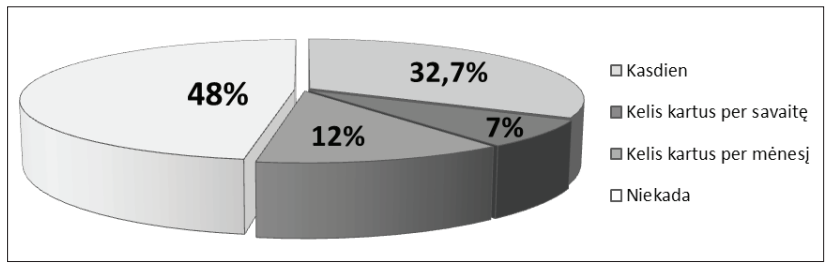

1 pav. Ar jūrininkai dažnai rūko (dabartiniu metu) kartus per savaitę (1 pav.). Kasdien rūko 34,3 proc. miesto gyventojų ir 26,2 proc. kaimo gyventojų. Statistiškai reikšmingi skirtumai tarp miesto ir kaimo gyventoju pagal ši požymį nenustatyti $\left(x^{2}=3,080 ; 11 s=3 ; p=0,379\right)$.

Tyrimo metu buvo klausiama, kaip dažnai mankštinasi jūrininkai. Atlikus duomenų analizę paaiškèjo, kad kasdien mankštinasi tik apie penktadalis tiriamuju (18,3 proc.). Šiek tiek daugiau nei pusè respondentu $-55,8$ proc. - sportuoja kelis kartus per savaitę ( 2 ir daugiau kartu). 16,3 proc. tiriamujų teigè sportuojantys kelis kartus per mènesį, o apie dešimtadalis $(9,6$ proc.) jūrininkų nurodè, kad jie niekada nesimankština. Visos grupès duomenų pasiskirstymas matomas antrame paveiksle (2 pav.). Atlikus duomenų analizę pagal tai, kaip mankštinasi ar sportuoja didžiają savo gyvenimo dalį mieste ir kaime/rajone praleidę respondentai - nebuvo nustatyti statistiškai reikšmingi skirtumai $\left(\mathrm{x}^{2}=5,160\right.$; $11 \mathrm{~s}=3 ; \mathrm{p}=0,160)$.

Apklausos metu tiriamujų buvo klausiama apie burnos higieną. Daugiau nei pusė apklaustujų (53,4 proc.) dantis valo kelis kartus per dieną, o apie du penktadaliai respondentu (38 proc.) dantis valosi 1 kartą per dieną. 6,7 proc. tiriamujų dantis valosi ne kiekvieną dieną (4 pav.). Apie 2 procentus jūrininkų dantų nesivalo niekada. Statistiškai reikšmingų skirtumų tarp didžiają savo gyvenimo dalị mieste ar kaime/rajone pragyvenusių apklaustujų pagal dantų valymosi ypatumus nebuvo nustatyta $\left(x^{2}=0,748\right.$; $11 \mathrm{~s}=3 ; \mathrm{p}=0,862$ ).

Apklausiant respondentus buvo domètasi, ar jūrininkai nešioja akinius bei lęšius. Šiek tiek daugiau nei ketvirtadalis apklaustuju (26,9 proc.) nešioja akinius ar lęšius, o dauguma jūrininkų (73,1 proc.) - akinių ir lęšių nenešioja. Atlikus statistinę duomenų analizę pagal gyvenamają vietą paaiškejjo, kad regos ypatumai tarp miesto ir kaimo/rajono gyventojų yra panašūs $\left(\mathrm{x}^{2}=2,814 ; 11 \mathrm{~s}=1 ; \mathrm{p}=0,093\right)$.

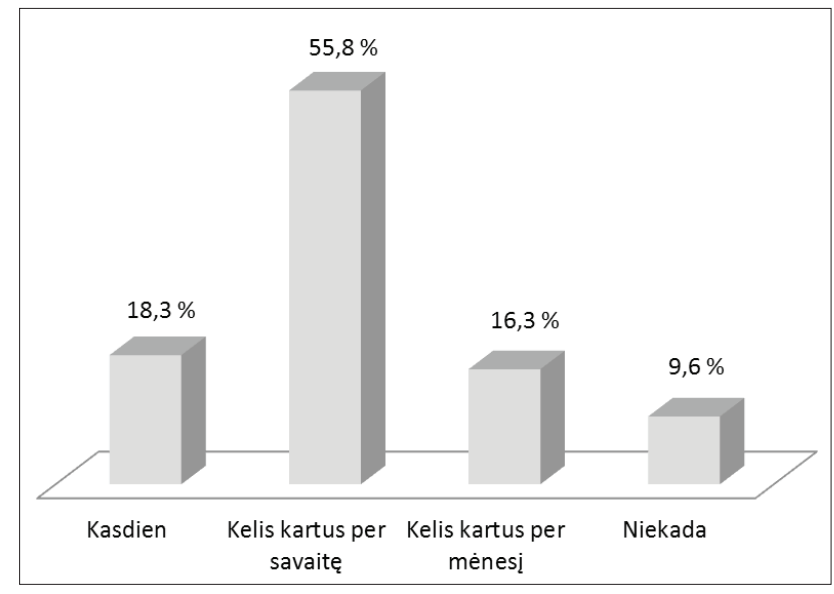

2 pav. Ar dažnai jūrininkai mankštinasi 


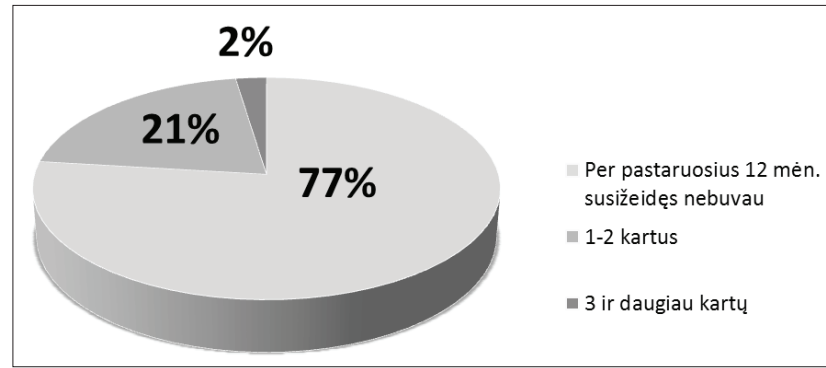

3 pav. Jūrininkų sužalojimai per pastaruosius 12 mėnesių

Tyrimo metu paaiškèjo, kiek kartų per pastaruosius 12 mènesių tiriamieji kreipèsi ị medikus, kai susižeidè ar patyrè nelaimingą atsitikimą. Dauguma respondentų $(76,9$ proc.) teigè nebuvę susižeidę per pastaruosius 12 mènesių, penktadalis tiriamujų (20,7 proc.) buvo sužaloti 1-2 kartus per pastaruosius dvylika mènesių. Maža dalis - tik 2,4 procentai respondentų per pastaruosius 12 mènesių dèl sužeidimų ar nelaimingų atsitikimų i medikus kreipesi 3 ir daugiau kartų (3 pav.). Skirtumai tarp didžiają savo gyvenimo dali pragyvenusių mieste ir kaime/rajone jūrininkų pagal šị požymị buvo statistiškai reikšmingi $\left(x^{2}=9,048\right.$; $11 \mathrm{~s}=2 ; \mathrm{p}=0,011)$. Dažniau susižeidžia kaimo gyventojai. 81,3 proc. didžiają gyvenimo dali mieste pragyvenusių tiriamujų ir apie 60 proc. didžiają savo gyvenimo dalį rajone/ kaime pragyvenusių respondentų per pastaruosius 12 mènesių nebuvo susižeidę. 1-2 kartus ị medikus dèl sužalojimų kreipèsi 16,9 proc. miesto ir 35,7 proc. kaimo/rajono gyventojų.

Per pastaruosius 12 mėnesių nesirgo 55,3 proc. jūrininkų, o 39,4 proc. -lankèsi pas gydytoją 1-2 kartus. Miesto gyventojai reikšmingai sveikesni nei kaimo $\left(\mathrm{x}^{2}=10,565\right.$; $11 s=2 ; p=0,005)-60,8$ proc. respondentų, kurie didžiają dali savo gyvenimo praleido mieste, ir 33,3 proc. kaime gyvenančių ar gyvenusių respondentų per pastaruosius dvylika mènesių nesirgo.

Apklausos metu buvo nustatyta, kaip jūrininkai vertina savo sveikatą. 28, 4 proc. tiriamujų mano, kad jų sveikata yra labai gera, 50,5 proc. - gera, 20,2 proc. - vidutinè. Tiek miesto, tiek kaimo gyventojai (skirstant pagal tai, kur respondentai gyveno ar gyvena didžiąą dali savo gyvenimo) vertina savo sveikatą panašiai $\left(\mathrm{x}^{2}=0,819 ; 11 \mathrm{~s}=3 ; \mathrm{p}=0,845\right)$. 28,9 proc. miesto gyventojų ir 26,2 proc. kaimo gyventoju mano, kad ju sveikata yra labai gera, o 49,4 proc. miesto gyventojų ir 54,8 proc. kaimo gyventojų mano, kad jų sveikata yra gera.

Tyrimas atskleide jūrininkų gyvensenos veiksnių ypatumus. Nors didžioji dauguma jūrininkų yra anksčiau rūkę, šiuo metu apie pusę tiriamujų nerūko, o kasdien rūko trečdalis jūrininkų. Tai rodo, kad reikètų plètoti švietimo bei

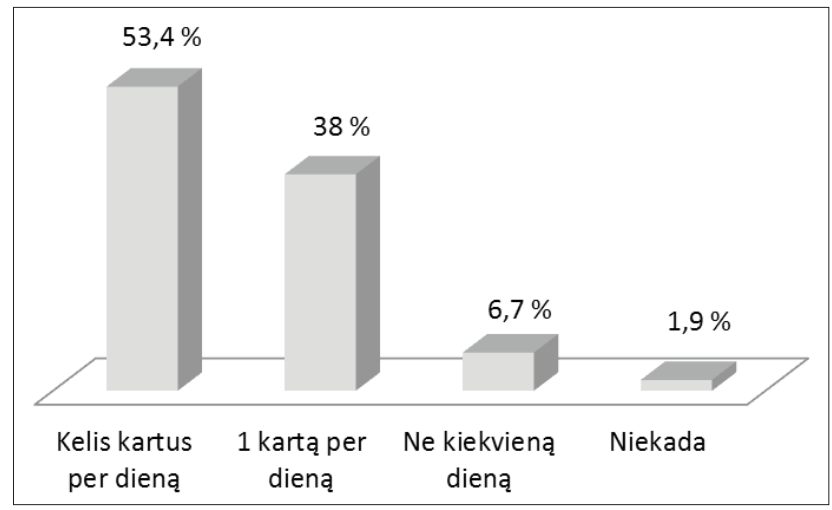

4 pav. Dantų valymas tarp jūrininkų

prevencinę veiklą, kad jūrininkai vengtų šio žalingo ịpročio. Pozityvu yra tai, kad jau pusè jūrininkų rodo tinkamą pavyzdị savo kolegoms ir neberūko. Mažokai jūrininkų mankštinasi kasdien. Dar yra jūrininkų, kurie iš viso nesimankština arba mankštinasi tik retkarčiais (kelis kartus per mènesị). Yra tokių, kurie neturi higienos ịgūdžių ir nesivalo dantų. Tai sudaro labai mažą tirtų respondentu dalį. Dauguma jūrininkų pasižymi geru regejjimu ir jiems nereikia nešioti akinių arba lęšių. Didžioji dauguma tirtų jūrininkų nebuvo susižeidę per pastaruosius metus. Tačiau pusè jūrininkų per pastaruosius 12 mènesių buvo susirgę. Tai pabrèžia, kad sveikatos stiprinimo, susirgimų prevencijos priemonių dar taikoma nepakankamai. Tyrimas parodè, kad apie penktadalis jūrininkų subjektyviai mano, jog jų sveikata yra tik vidutiné. Tokia sveikata yra nepakankama sunkiomis sąlygomis jūroje dirbantiems žmonèms. Taigi daugiau dèmesio turètų būti skiriama būsimų ir jau dirbančių jūrininkų sveikos gyvensenos švietimui ir mokymui bei jų sveikos gyvensenos ịpročių ugdymui. J. Sąlyga jūrininkų sveikatos tyrimuose taip pat teigè, kad jürininkai turètų daugiau dèmesio skirti sveikai gyvensenai, jos ịpročiams darbo jūroje metu [7]. V. Senčila ir kt. nurodo, kad sveikatos problemos yra viena iš pagrindinių priežasčių, dèl kurių jūrininkai nutraukia darbą jūroje [11]. Jūrininkų gyvensenos ir sveikatos problemas būtina toliau tirti ir analizuoti. Tai lieka aktualiais visuomenès sveikatos klausimais šioje tikslinèje visuomenès grupeje. Daugiau dèmesio reikètų skirti jūrininkų sveikos gyvensenos ịgūdžių formavimui.

\section{Išvados}

1. Didžioji dauguma jūrininkų (87 proc.) yra kada nors rūkę per savo gyvenimą. Dabar apie pusė tiriamųjų nerūko, trečdalis jūrininkų rūko kasdien, 7,2 proc. respondentu rūko kelis kartus per savaitę.

2. Kasdien mankštinasi tik apie penktadalis tiriamujų. 
Daugiau nei pusė $(55,8$ proc.) respondentų sportuoja kelis kartus per savaitę ( 2 ir daugiau kartų), 16,3 proc. tiriamuju sportuoja kelis kartus per mènesį, o dešimtadalis jūrininkų niekada nesimankština.

3. Daugiau nei pusè apklaustujų dantis valo kelis kartus per dieną, apie du penktadaliai respondentų ( 38 proc.) dantis valosi 1 kartą per dieną, 6,7 proc. tiriamujų dantis valosi ne kiekvieną dieną, o apie 2 procentus jūrininkų dantų nesivalo niekada.

4. Dauguma jūrininkų (73,1 proc.) akinių ir lęšių nenešioja.

5. Per pastaruosius 12 mėnesių dauguma respondentų (76,9 proc.) nebuvo susižeidę, penktadalis tiriamujų buvo sužaloti 1-2 kartus ir tik 2,4 procentai respondentų dèl sužeidimų ar nelaimingų atsitikimų i medikus kreipèsi 3 ir daugiau kartų. Dažniau susižeidžia kaimo gyventojai. Per pastaruosius 12 mènesių nesirgo apie pusè (55,3 proc.) jūrininkų.

6. 28,4 proc. tiriamujų mano, kad jų sveikata yra labai gera, 50,5 proc. - gera, 20,2 proc. - vidutinè. Jūrininkų švietimui, jų sveikos gyvensenos igūdžių formavimui reikètų skirti daugiu dèmesio (ypač kaimo/rajono gyventojams).

\section{Literatūra}

1. Saarni H, Jokinen J, Juusela AK, Visuri S. Who benefits from group-based health promotion? A pilot study among Finnish seafarers. Archives des Maladies Professionnelles et de 1‘Environnement 2013; 74(5): 562.

2. Guo JL, Liang GS. Sailing into rough seas: Taiwan`s women seafarers'career development struggle. Women's studies international forum 2012; 35(4): 194-202.

3. Jezewska M, Leszczynska I, Grubman-Nowak M. Quaity of life of Polish seafarers. Archives des Maladies Professionnelles et de 1'Environnement 2013; 74(5): 570-571.

4. Carter T. Working at sea and psichosocial problems. Travel medicine and infectious disease 2005; 3(2): 61-65.

5. Sąlyga J. Jūrininkų privalomo sveikatos tikrinimo tvarkos vertinimas ir galimas tobulinimas. Sveikatos mokslai, 2010; 5(20): 3483-3487.

6. Senčila V., Bartusevičienė I., Kalvaitienė G. Lietuvos jūrininkų sudèties kiekybinis ir kokybinis vertinimas. Jüra ir aplinka, 2006; 1(14): 7-15.

7. Salyga J. Specialities of Lithuanian and Latvian seafarer's life style in the sea. J. Innovative Medicine and Biology 2011; 1: $41-53$.

8. Sąlyga J. Lietuvos ir Latvijos jūrininkų gyvensenos ypatumai ir veiksniai, skatinantys psichoemocinę itampą jūroje. Visuomenès sveikata, 2005; 2(29): 3-10.

9. Sąlyga J, Juozulynas A, Lukšienė A. Health problems of Lithu- anian and Latvian seamen. Acta Medica Lituanica 2006; 13 : $38-46$.

10. Norkienẻ S., Sąlyga J. Lietuvos jūrininkų su sveikata susijusi gyvenimo kokybė ir sąsajos su kūno masės indeksu. Sveikatos mokslai, 2009; 2(19): 2267-2271.

11. Senčila V, Kalvaitienè G, Bartusevičienè I. Modeling of seafarers' age profile influence on their future staff: case of Lithuania. Proceedings of International Conference on Human Performance at Sea HPAS. Glasgow, Scotland, UK, 2010; $107-$ 116.

\section{SEAFARERS' LIFESTYLE AND HEALTH IN LITHUANIA}

\section{B. Strukčinskienė, I. Bartusevičienė, V. Strukčinskaitė,}

\section{S. Norkienè}

Key words: seafarers, lifestyle, health, health promotion.

Summary

The analysis of seafarers' lifestyle and health, are of great importance for promoting seafarers' health. The survey on seafarers' lifestyle and health was accomplished in Lithuania. In the survey participated 208 full time and half time students (already working ones and the future seafarers) of Lithuanian Maritime Academy. More respondents (79.8 \%) most of their lifetime lived in urban area, and $20.2 \%$ lived in rural area. Chi-square test was used and the significance level $\mathrm{p} \leq 0.05$ was considered statistically significant.

The study revealed that the majority of seafarers $(87 \%)$ have tried to smoke at least once in their lifetime. One third of investigated seafarers now are smoking daily, about half of respondents do not smoke at all, and 7.2\% - smoke few times per week. Only one-fifth of seafarers exercise every day, more than a half of respondents $(55.8 \%)$ do sports few times per week, $16.3 \%$ exercise few times per month, and about $10 \%$ - never exercise. More than half of respondents brush their teeth few times per day, $38 \%$ - brush their teeth once a day, $6.7 \%$ - brush their teeth not every day, and $2 \%$ of investigated seafarers never brush their teeth. The majority of seafarers $(73.1 \%)$ do not use glasses or contact lenses. During the last 12 months, the majority of respondents $(76.9 \%)$ were not injured, a one-fifth of seafarers were injured 1-2 times, only $2.4 \%$ were injured three and more times. Rural respondents were injured more often than urban ones. About one third (28.4\%) of seafarers subjectively think, as their health is very good. During the last 12 months, about half (55.3\%) of investigated seafarers were not ill. Education and healthy lifestyle formation in seafarers needs more attention.

Correspondence to: birutedoctor@hotmail.com

Gauta 2014-06-04 